\title{
Golden Parachutes and the Wealth of Shareholders
}

\section{Citation}

Bebchuk, Lucian A., Alma Cohen, and Charles C.Y. Wang. "Golden Parachutes and the Wealth of Shareholders." Journal of Corporate Finance 25 (April 2014): 140-154.

\section{Published Version}

http://dx.doi.org/10.1016/j.jcorpfin.2013.11.008

\section{Permanent link}

http://nrs.harvard.edu/urn-3:HUL.InstRepos:12534954

\section{Terms of Use}

This article was downloaded from Harvard University's DASH repository, and is made available under the terms and conditions applicable to Open Access Policy Articles, as set forth at http:// nrs.harvard.edu/urn-3:HUL.InstRepos:dash.current.terms-of-use\#OAP

\section{Share Your Story}

The Harvard community has made this article openly available.

Please share how this access benefits you. Submit a story.

Accessibility 
Latest revision: October 2013

\title{
Golden Parachutes and the Wealth of Shareholders
}

\author{
Lucian Bebchuk, ${ }^{*}$ Alma Cohen, ${ }^{* *}$ and Charles C.Y. Wang ${ }^{* * *}$
}

\begin{abstract}
$\underline{\text { Abstract }}$
Golden parachutes (GPs) have attracted substantial attention from investors and public officials for more than two decades. We find that GPs are associated with higher expected acquisition premiums and that this association is at least partly due to the effect of GPs on executive incentives. However, we also find that firms that adopt GPs experience negative abnormal stock returns both during and subsequent to the period surrounding their adoption. This finding raises the possibility that even though GPs facilitate some value-increasing acquisitions, they do have, on average, an overall negative effect on shareholder wealth; this effect could be due to GPs weakening the force of the market for control and thereby increasing managerial slack, and/or to GPs making it attractive for executives to go along with some value-decreasing acquisitions that do not serve shareholders' long-term interests. Our findings have significant implications for ongoing debates on GPs and suggest the need for additional work identifying the types of GPs that drive the identified correlation between GPs and reduced shareholder value.
\end{abstract}

Keywords: Golden parachute, executive compensation, corporate governance, acquisitions, takeovers, acquisition likelihood, acquisition premiums, agency costs, managerial slack, DoddFrank.

JEL Classifications: D23, G32, G38, J33, J44, K22, M14.

\footnotetext{
${ }^{*}$ Harvard Law School and NBER

${ }^{* *}$ Tel-Aviv University Eitan Berglas School of Economics, Harvard Law School, and NBER

${ }^{* * *}$ Harvard Business School

We benefited from the helpful comments of Sanjai Bhagat, Allen Ferrell, Jesse Fried, Jarrad Harford, an anonymous referee, and workshop and conference participants at Harvard, Stanford, Michigan, the ALEA annual meeting, and Yale SOM. We also thank Kyle Thomas for his excellent research assistance.
} 


\section{Introduction}

Golden parachutes (GPs) became common in the late 1970s and early 1980s in the midst of unprecedented takeover activity, and they have attracted much debate and substantial attention from investors and public officials ever since. In 1984, Congress enacted Sections $280 \mathrm{G}$ and 4999 of the Internal Revenue Code, which seek to discourage GPs with high monetary value by imposing substantial tax penalties on their use. Over the past 15 years, precatory resolutions opposing GPs have been brought in significant numbers and have generally passed. The 2010 Dodd-Frank Act mandated advisory shareholder votes on all future adoptions of GPs by public firms.

In this paper, we contribute to the ongoing debate about GPs by using a long panel dataset from 1990 to 2007 to empirically assess the effects of GPs. We show that even though GPs are associated with higher expected acquisition premiums, they could reduce the value overall for shareholders.

The first part of our paper focuses on the effect of GPs on unconditional expected acquisition premiums (i.e., expected premiums), which is a product of the likelihood of an acquisition and the premiums that are conditional on an acquisition. There is a substantial empirical literature examining how GPs are associated with the likelihood of an acquisition and with premiums in the event of an acquisition (see, most recently, Sokolyk 2011; and Fich, Tran, and Walkling 2013). ${ }^{1}$ Our work, however, is the first to provide an integrated analysis combining the effects of GPs on both acquisition likelihood and premiums. We find that GPs are associated with higher expected acquisition premiums; even though GPs

\footnotetext{
${ }^{1}$ Earlier studies examining the relationship of GPs with acquisition likelihood include Harris (1990); Machlin, Choe, and Miles (1993); Cotter and Zenner (1994); Born and Trahan (1993); Hall and Anderson (1997); Agrawal and Knoeber (1998); Lefanowicz, Robinson, and Smith (2000); and Bates, Becher, and Lemmon (2008). Most (but not all) of these studies find a positive association between GPs and acquisition likelihood.

As to the relationship of GPs with premiums in the event of an acquisition, Machlin, Choe, and Miles (1993) report a positive correlation between the size of GPs and acquisition premiums. Fich, Tran, and Walkling (2013) find a negative association between GPs and premiums in the event of an acquisition. Sokolyk (2011) finds no statistically significant relationship between GPs and acquisition premiums. Hartzell, Ofek, and Yermack (2004) present related findings, which we discuss in Section 4 below.
} 
are associated with lower premiums in the event of an acquisition, their association with a higher acquisition likelihood turns out to dominate the lower premium effect. ${ }^{2}$

Furthermore, we add to the literature by showing that the positive associations between GPs with higher acquisition likelihood and higher expected premiums are not wholly due to the "private information," or signaling explanation (Lambert and Larcker 1985), which argues that GPs are adopted when managers have private information indicating a high likelihood of acquisition. Instead, our findings show that these positive associations are at least partly driven by the effect of GPs on executives' incentives, under which acquisitions become more attractive to managers (Lambert and Larcker 1985; Jensen 1988; Kahan and Rock 2002). ${ }^{3}$ If these associations were solely driven by the signaling explanation, we would expect them to be driven by "fresh" GPs (i.e., GPs that were recently adopted). We find, however, that both "fresh" and "older" GPs are positively and significantly associated (with similar magnitudes) with acquisition likelihood as well as with unconditional expected premiums. These findings are thus consistent with the possibility that the positive associations between GPs and both acquisition likelihood and expected premiums are at least partially due to the effect on executives' incentives.

The second part of our paper, which provides the paper's most important contribution, assesses the overall effect of GPs by examining the evolution stock prices prior to, around, and after the adoption of GPs. Bebchuk, Cohen, and Ferrell (2009) note that GPs are negatively correlated with firm value, but they do not identify the extent to which this association is driven by a selection effect (a tendency of low-value firms to have GPs) and/or by post-adoption changes. Focusing on stock returns over time enables us to examine the overall impact of GPs on shareholder value by combining the effects through takeover premium channels and stand-alone value channels.

\footnotetext{
${ }^{2}$ An analysis of the relationship of GPs and expected acquisition premiums was introduced in our working paper (Bebchuk, Cohen, and Wang 2010). Fich, Tran, and Walkling (2013) adopt an approach similar to ours and obtain consistent results.

${ }^{3}$ Our results are thus consistent with and complement the significant body of literature showing how acquisition decisions are influenced by managers' private interests (see, e.g., Brickley, Coles, and Terry 1994; Cotter and Zenner 1994; Cotter, Shivdasani, and Zenner 1997; Grinstein and Hribar 2004; Wulf 2004; and Jenter and Lewellen 2011).
} 
We show that firms tend to experience erosion in shareholder value prior to GP adoption and that this erosion continues around and subsequent to GP adoption. In particular, we find that (i) among firms that do not have GPs, those that adopt them by the next Investor Responsibility Research Center (IRRC) volume experience lower abnormal stock returns during the intervolume period (i.e., the period between two consecutive IRRC volumes) than firms that do not adopt them by the next IRRC volume, (ii) firms that adopt GPs and maintain them in the long run experience lower abnormal stock returns following adoptions than firms that do not have GPs and do not adopt them subsequently, and (iii) the post-adoption negative abnormal returns persists even when we include the acquisition premiums earned by the acquired firms.

The findings on the erosion of shareholder value following GP adoption could be at least partly driven by a "managerial slack" effect: such an effect can occur with a weakening of the discipline of the market for corporate control (Shleifer and Vishny 1989; Gompers, Ishii, and Metrick 2003), and GPs weaken this market discipline by making managers less fearful of acquisitions (Bebchuk, Cohen, and Ferrell 2009). In addition, the erosion of value following GP adoption could be at least partly driven by a "selling-out" effect: executives might have some private information about the long-term independent value of their company, and GPs that are large enough might give them incentives to go along with an acquisition even when the their private information indicates that doing so would not be in the shareholders' long-term interest. However, our finding about the relationship between GPs and shareholder value provide no support for the view that, by weakening the pressures of the market for corporate control, GPs bring about increased firm value by inducing more focus on the long term (Stein 1988) or by encouraging executives to invest in firm-specific human capital (Jensen 1988; Shleifer and Vishny 1989).

Because our stock return results include gains from acquisitions, our findings suggest that, notwithstanding their beneficial impact on acquisition premiums, the net overall effect of GPs is, on average, negative. Thus, our analysis reaches a less favorable conclusion concerning the use of GPs than 
does much of the literature, which has focused on the effect of GPs on acquisitions and not on their overall effect on shareholder value.

We would like to stress the "on average" aspect of our conclusion that GPs are, on average, associated with reduced value for shareholders. Our findings do not rule out the possibility that the use of certain types of GPs or of GPs in certain circumstances may have overall positive effects on shareholder wealth. Identifying which uses of GPs drive our "on average" results and which uses, if any, have overall positive effects on shareholder wealth is an interesting subject for future empirical work.

The remainder of this paper is organized as follows. Section 2 describes our data sources and provides summary statistics. Section 3 analyzes the relationship between GPs and expected acquisition premiums. Section 4 analyzes the relationship between GPs and evolution of firm value over time. Section 5 presents our conclusion.

\section{Data and Summary Statistics}

\subsection{The Data}

Our data on GPs come from the eight volumes published by IRRC on the following dates: September 1990, July 1993, July 1995, February 1998, November 1999, February 2002, January 2004, and January 2006. Each IRRC volume tracks a wide range of corporate governance provisions, including the variable of interest "Golden Parachute" - a binary variable indicating whether a firm has a GP at each of the above publication dates - for 1,400 to 2,000 firms that comprise the S\&P500 and other firms that IRRC considers to be important.

The IRRC dataset offers at least three distinct advantages for the study of GPs. First, IRRC provides comprehensive coverage of firms: any given IRRC volume covers over $90 \%$ of the combined market capitalization of the AMEX, NYSE, and NASDAQ exchanges. Second, this dataset data set allows us to construct a long time series spanning almost 20 years. Third, IRRC tracks a host of other corporate governance provisions for a given firm, allowing researchers to control for the structure and strength of 
corporate governance when identifying the effect of GPs on takeover likelihood, acquisition premiums, and shareholder value.

To conduct our analyses, we construct two panel datasets based on the IRRC data that are merged with the CRSP-Compustat merged sample (CCM): one dataset is updated annually; the other is updated on each IRRC publication date. The annual dataset is constructed as follows: Since governance data are updated every two to three years, we impute the intervolume values of the governance provisions using the forward-fill method of Gompers, Ishii, and Metrick (2003) (GIM). ${ }^{4}$ The forward-fill results in an annual dataset of governance provisions that we merge with annual financial data from CCM according to fiscal year and permno (the CRSP firm identifier). The volume-by-volume dataset is constructed by merging the eight volumes of IRRC governance data with CCM according to the fiscal year ending closest and prior to the current date of each IRRC volume.

The strength of the annual dataset is the increased sample and the higher frequency with which we observe relevant firm outcomes (e.g., being taken over) and other financial characteristics (e.g., Tobin's Q). The strength of the volume-by-volume dataset is the accuracy in the governance data, which is up-todate as of the publication date of each IRRC volume. Our analyses use the strengths of both datasets to establish the associations of GPs with acquisition likelihood, acquisition premiums conditional on a bid, and ex-ante premiums. We also use the volume-by-volume dataset to explore the evolution of firm valuation and returns prior to, around, and after GP adoptions.

For both datasets, our analyses exclude dual-class firms and real estate investment trusts, following GIM, because of these firms' unique governance structures and regulations. We also merge ExecuComp data to incorporate information on firm chief executive officer (CEO) and insider characteristics, such as CEO age, tenure, and top-five insider ownership.

For our analysis of takeover likelihood and takeover premiums, we code as acquisitions all deals designated as "Mergers," "Acquisitions," and "Acquisitions of Majority Interest" from Securities Data

\footnotetext{
${ }^{4}$ We also attempt different filling methods, such as backward filling and random filling, and find our results to be robust to the choice of filling method.
} 
Company (SDC) Platinum. Spinoffs in which the acquirers are shareholders of the firm are excluded from our sample. Permnos for target firms are obtained by matching target firm CUSIPs, or by hand matching target names if CUSIP matches are not found. This results in a final sample of 10,856 announced takeover bids from 1990 to 2007 , covering 9,277 target firms. Using these data, we follow the procedure described in Bates and Lemmon (2003) to assign auction sequences and identify initial bids in an auction. (An "initial bid" is when there is no announced takeover bid 365 calendar days prior to the announcement date and a "follow-on bid" is when another takeover attempt is announced within 365 calendar days prior to a bid.) Our analysis of takeover premiums focuses on the one-week and four-week acquisition premiums, as reported in SDC, which are the price per share paid by the acquirer divided by the target price one week and four weeks prior to the announcement date. Finally, these data are merged with our annual and volume-by-volume IRRC data by CRSP identifier, yielding 1,418 initial bids and 1,081 completed acquisitions in our sample.

For the annual dataset we define two primary variables of interest for our analyses of takeover likelihood: an indicator that a firm receives an initial bid in the calendar year following the current year of the IRRC volume ("Received Bid Next Year") and an indicator that a firm is acquired in the calendar year following the current year of the IRRC volume ("Acquired Next Year"). To illustrate, a firm that receives a bid and is acquired in the year 2002 receives bid $=1$ and acquired $=1$ in the data matched to the 2001 IRRC volume. Similarly, for the volume-by-volume merged sample, we define the following two primary variables: an indicator that a firm receives an initial bid by the current date of the following IRRC volume ("Received Bid by Next IRRC Vol") and an indicator that a firm is acquired by the current date of the following IRRC volume (“Acquired by Next IRRC Vol”).

\subsection{Summary Statistics}

Table 1 reports summary statistics on the stock and adoption of GPs in each of the eight IRRC volumes. Panel A shows that the use of GPs has become increasingly prevalent: $50.44 \%$ of firms in the 1990 volume have GPs compared to $77.65 \%$ in the 2006 volume. Panel B summarizes the incidence of 
GP adoption during each intervolume period. We consider a firm a GP adopter if, in the first of two consecutive IRRC volumes, it did not have a GP but had a GP in the subsequent volume. ${ }^{5}$ We find that from 1990 to 2002, the percentage of eligible adopters that adopted GPs in the intervolume period steadily rose from $15.81 \%$ to $30.02 \%$ and declined thereafter to $21.98 \%$ in the 2006 volume. On average (weighted), 22.29\% of eligible adopters adopted a GP in the intervolume period. GP removals also occurred, but they were uncommon: in any IRRC volume, less than 5\% of firms with GPs dropped them by the following volume.

Table 2 compares the characteristics of firms with and without GPs. For each group, we report univariate summary statistics on means and standard deviations, as well as significance levels from an unpaired two-sided t-test. Firms with GPs differ from those without them in terms of financial and industry characteristics, governance structure, and acquisition likelihood. GP firms have lower industryadjusted market capitalization, lower industry-adjusted Tobin's Q's, and higher industry-adjusted debt-toasset ratios. ${ }^{6}$ Furthermore, GP firms are less likely to be Delaware incorporated and from industries with greater product market competition as measured by the Herfindahl Index. ${ }^{7}$ These univariate statistics suggest that firms with GPs face greater threat of takeover. Moreover, these firms are also associated with greater protection from takeovers; that is, they are more likely to have a classified board, a poison pill, and provisions other than a GP from either the EIndex (Bebchuk, Cohen, and Ferrell 2009) or the GIndex (Gompers, Ishii, and Metrick 2003).

Finally, Table 3 provides summary statistics on the relationship between GPs and acquisitions. During the 1990-2006 period, the percentage of firms with GPs that received an acquisition bid or were

\footnotetext{
${ }^{5}$ Clearly, this requires the firm to be covered in two consecutive volumes. All such firms are considered "eligible adopters."

${ }^{6}$ Relative market capitalization of a firm is defined as a firm's market capitalization divided by the median market capitalization of all firms covered in CRSP in that year. Tobin's Q is the ratio of the market value of assets to the book value of assets, where the market value of assets is computed as book value of assets plus the market value of common stock less the sum of book value of common stock and balance sheet deferred taxes (following Kaplan and Zingales 1997). Industry-adjusted Tobin's Q is equal to Tobin's Q minus the median Tobin's Q in the industry. Industry relative debt-to-asset ratio is defined as the debt-to-asset ratio minus the industry median debt-to-asset ratio. All industry relative measures above use SIC 2-digit definitions.

${ }^{7}$ Following Giroud and Mueller (2011), we define the Herfindahl index based on SIC 3-digit industry definitions.
} 
acquired in the following calendar year is consistently greater than the percentage of firms without GPs that received an acquisition bid or were acquired in the following calendar year. On average, $6.68 \%$ of firms with GPs received an acquisition bid in the next year compared to $4.67 \%$ of firms without GPs, a $43 \%$ higher likelihood; the average time series difference of $2.01 \%$ is statistically significant at the $1 \%$ level based on a standard two-tailed t-test.

Moreover, on average, $5.18 \%$ of firms with GPs were successfully acquired in the following year compared to $3.41 \%$ of firms without GPs, a $52 \%$ higher likelihood; the average time series difference of $1.76 \%$ is statistically significant at the $1 \%$ level based on a standard two-tailed t-test. In Section 3 below, we extend this univariate analysis and examine the roles played by incentive and private information effects in the relationship between a GP and a higher likelihood of bids.

\section{GPs and Expected Acquisition Premiums}

We begin our analysis by examining the association between GPs and expected acquisition premiums, which are a product of (i) acquisition likelihood and (ii) premium conditional on an acquisition. Below, we first study the association between GPs and each of these elements separately (Sections 3.1 and 3.2) and then proceed to examine the association between GPs and expected premiums (Section 3.3). Finally, we examine whether the positive association identified between GPs and expected premiums, as well as the positive association between GPs and acquisition likelihood that drives it, are at least partly due to the effect of GPs on incentives rather than a reflection of the influence of private information (Section 3.4).

\subsection{GPs and Likelihood of Acquisition}

The summary statistics above indicate that GPs are correlated with a firm's increased likelihood of receiving an offer and of being acquired. However, such correlation might be due to GPs being associated with publicly observed variables that are known to be correlated with the likelihood of receiving a bid or of being acquired. Such association can arise if executives of firms with such variables rationally exert 
greater effort to obtain GPs. Indeed, the summary statistics above indicate that GPs are associated with publicly observable variables known to be correlated with bids and acquisitions, such as lower firm size and lower industry-adjusted Q. However, the question remains: can GPs be expected to be correlated with bids and acquisitions after controlling for such variables?

We explore two hypotheses. First, the incentive hypothesis posits that GPs are expected to be positively correlated with bids and acquisitions (controlling for variables known to be correlated with bids and acquisitions). By providing executives with an additional monetary benefit in the event of an acquisition, GPs lower the premium threshold above which an acquisition would be in the executives' private interests, notwithstanding their loss of some private benefits of control (Lambert and Larcker 1985; Jensen 1988). Second, the private information hypothesis predicts that, even when one controls for publicly observable variables that are associated with an increased likelihood of bids and acquisitions, an executive may have private information that his or her company is more likely to receive a bid or be acquired than is suggested by the publicly observable variables. An executive who has such private information will place greater weight on having a GP (Lambert and Larcker 1985). Thus, this hypothesis also predicts a positive association between GPs and the likelihood of receiving a bid or being acquired.

Using our annual dataset, we confirm the predictions of these hypotheses empirically by estimating, via a probit model, the likelihood of a firm receiving a bid in the next calendar year ("Receive Bid Next Year") and the likelihood of a firm being acquired in the next calendar year ("Acquired Next Year") as a function of whether the firm has a GP and other controls. In unreported tests, we find qualitatively similar results with respect to the associations between GPs and acquisition likelihood using a logit specification and using a hazard model specification. We control for other corporate governance provisions using three additional variables: "EIndex-GP," the Entrenchment Index minus GP; "GIndex-EIndex," the GIM index minus the value of the Entrenchment Index; and "Delaware Inc," an indicator of whether the firm is incorporated in Delaware. ${ }^{8}$

\footnotetext{
${ }^{8}$ In light of the work of Sokolyk (2011), we verify that our results are robust to the inclusion of "Compensation Plan"- one of the components of the GIndex not included in the EIndex - as a separate explanatory variable.
} 
Our other financial control variables reflect values in the current fiscal year. " $\log (\mathrm{Q})$ " refers to the $\log$ of a firm's Tobin's Q; "Log(Assets)" is the log of a firm's total assets; and "Log(Debt/Asset)" is the $\log$ of a firm's debt-to-asset ratio. We also include controls for inside ownership (“Inside Ownership"), defined as the fraction of shares held by the top five executives (in terms of shares held); log of the CEO's age in years ["Log(CEO Age)"]; and log of the CEO's tenure in years ["Log(CEO Tenure)"]. We control for industry effect by either the Herfindahl-Hirschman Index (Herfindahl Index), representing the level of product market competition in the industry, or by 2-digit SIC (SIC2) industry fixed effects. Our use of the Herfindahl Index follows the work by Giroud and Mueller (2011), which documents the possibility that corporate governance may matter only for industries with low product market competition. We also include year fixed effects.

Pooled probit estimation results, whose marginal effects evaluated at the means are reported in Table 4, find a consistent positive association between GPs and the likelihood of an acquisition bid as well as of a completed acquisition across our specifications, controlling for firm characteristics and strength of takeover protection. The fact that results for takeover likelihood are consistent with those for bid likelihood is not surprising since $70 \%$ of the auction sequences identified in our sample resulted in completed acquisitions in our sample, with an average length to completion (from initial bid) of 167 days.

Columns (1) and (3) of Table 4, which use the Herfindahl Index as the control for industry (instead of using industry fixed effects), report the marginal effect of GPs on bid likelihood and takeover likelihood for the average firm (i.e., one that holds the mean values for the control variables) to be $1.48 \%$ and $1.28 \%$, with statistical significance at the $1 \%$ level for both. The increase in bid and takeover likelihoods amounts to a $26.1 \%$ proportional increase in the likelihood of takeover bids and a $32.2 \%$ proportional increase in the likelihood of acquisition. Therefore, the association between GPs and the higher likelihood

Sokolyk (2011) finds that GPs and compensation plans have positive and significant association with the likelihood of an acquisition, but when modeling acquisition premiums, GPs are not significant while compensation plans are. To examine whether our results are affected by the inclusion of a compensation plan, we split GIndex-EIndex into two parts: (i) a dummy that is equal to 1 if a firm has a compensation plan and (ii) a variable that is equal to all other provisions that are in GIndex that are not included in EIndex and are not compensation plans.. Using this specification does not change our results in this and subsequent sections. 
of a bid as well as of a completed acquisition, is both statistically and economically meaningful. The marginal effects reported in columns (2) and (4), which include SIC2 industry fixed effects, are nearly identical in magnitude and statistical significance to those reported in columns (1) and (3).

These empirical results are consistent with predictions from both the incentive and private information hypotheses. That is, controlling for variables known to correlate with acquisition likelihood, GPs are positively associated with acquisition likelihood in a significant and economically meaningful way.

\subsection{GPs and Premiums in the Event of an Acquisition}

In the event of an acquisition, the effect of GPs on executive incentives can be expected to lower premiums through two channels. First, in those cases in which an acquisition would occur even in the absence of GPs, GPs weaken the incentives of executives to bargain hard. In addition, some lowerpremium bids - bids that would not have occurred in the absence of a GP — might become worthwhile for those executives once a GP is introduced.

It should be noted that there is an alternative reason for an association between low premiums and special payments to executives in connection with an acquisition — but one that does not seem to apply for most GPs in our dataset. Hartzell, Ofek, and Yermack (2004) examine situations in which CEOs negotiating an acquisition also obtain, with the explicit or implicit approval of the buyer, extra payments in the form of special bonuses or increased GPs. These authors find that CEOs who obtain such acquisition benefits tend to accept lower premiums for their shareholders. The authors reasonably interpret this pattern as reflecting a willingness of CEOs to accept a reduction in acquisition premiums in return for buyer willingness to let them derive ex post acquisition benefits not allocated to them ex ante. ${ }^{9}$ Unlike the acquisition benefits examined in their paper, for which executives negotiating an acquisition need to bargain, the benefits provided to executives under the GPs in our dataset are not ones for which executives need to bargain at the time they negotiate an acquisition. These GPs are adopted ex ante and

\footnotetext{
${ }^{9}$ Similarly, Wulf (2004) reports that in mergers of equals, CEOs seem to be willing to accept a lower premium for their shareholders when they are awarded a position in the post-merger combined firm.
} 
are already set and binding, so the executives need not take any step or make any concession in terms of the premium or otherwise in order to benefit from them.

Using our annual dataset, we confirm the predictions of the incentives hypothesis by estimating pooled regressions of one-week and four-week acquisition premiums on the presence of GPs and other controls, such as the firm's governance structure and financial characteristics. We also control for deal characteristics, such as the acquiring firm's toehold in the acquired firm's shares prior to the takeover announcement, whether a termination fee is in place, ${ }^{10}$ whether the acquisition attempt is hostile, whether the deal is a tender offer, and whether the deal involves a stock swap. Finally, we also proxy for the strength of the negotiating effort by including the time to completion in days ["Log(Time)"], and we control for target firms' CEO characteristics by including the log of CEO age and tenure.

Our analysis excludes those transactions in which the bidder and the target companies share the same parent company, as well as those transactions with non-negative acquisition premiums (840 non-missing for the one-week premium and 839 non-missing for the four-week premium), ${ }^{11}$ because these transactions reflect abnormal takeover circumstances. Including such transactions does not change our results qualitatively but generally weakens their statistical significance.

Pooled ordinary least squares (OLS) results reported in Table 5 show a consistent and negative association between GPs and acquisition premiums. Estimation results using the one-week and four-week premiums reported in columns (1) and (3) show that the presence of GPs is associated with an average reduction in acquisition premiums of 3.57 and 4.33 percentage points. In columns (2) and (4) we use the $\operatorname{logs}$ of acquisition premiums as the dependent variables because acquisition premiums are positively skewed. We find in these columns that the presence of a GP reduces one-week premiums by $12.8 \%$ and reduces four-week premiums by $19.2 \%$, an economically significant discount. With the exception of

\footnotetext{
${ }^{10}$ Typically, after target and acquiring boards reach a preliminary agreement, the impending deal is announced publicly and both sides await target shareholder approval. These preliminary agreements may include a termination clause requiring the target firm to pay a fee to the acquirer in the event that the target cancels the agreement in order to accept a competing bid.

${ }^{11}$ The 840 transactions with non-missing one-week premiums are not a superset of the 839 transactions with nonmissing four-week premiums. Fifteen observations in the former are not included in the latter, while 18 observations in the latter are not included in the former.
} 
column (2), the coefficient of GP is significant at the 5\% level. In summary, these findings of a negative association between GPs and acquisition premiums are consistent with the incentives hypothesis. ${ }^{12}$

\subsection{Unconditional Expected Premiums}

The above analysis suggests an ambiguous relationship between GPs and the ex ante unconditional expected premiums as a result of two counteracting effects. While the presence of GPs is associated with an increased likelihood of acquisition and thus the likelihood of realizing acquisition premiums, it is also associated with a decrease in the size of premiums in the event of an acquisition. The incentives hypothesis is consistent with and predicts these empirical patterns, but it does not generate a clear prediction on the product of these two effects. The relationship between GPs and the unconditional expected acquisition premiums is therefore an empirical issue.

We assess this empirical relation using the full sample of firms in our annual dataset, and we follow the methodology of Comment and Schwert (1995) by setting the acquisition premiums to zero for all nontakeover firm-year observations. Table 6 reports pooled OLS estimation results that are similar to those shown in Table 5, but it uses the full sample. As in Table 5, we consider one-week and four-week premiums in columns (1) and (3), respectively, and the log of the respective premiums in columns (2) and (4). ${ }^{13}$ However, in Table 6 we control for only those firm characteristics that can be observed ex ante (i.e., we ignore those specific to deal characteristics); moreover, we now interpret the coefficients of this model as marginal effects on the ex ante unconditional expected acquisition premiums, which combine GP effects on acquisition likelihood and the conditional acquisition premiums.

The results reported in Table 6 show a consistent and positive association between GPs and unconditional expected acquisition premiums. Estimation results using the one-week and four-week premiums reported in columns (1) and (3), respectively, show that the presence of GPs is associated with

\footnotetext{
${ }^{12}$ In unreported tests, we verify that these findings on the associations between GPs and acquisition likelihood and between GPs and acquisition premiums are robust to controlling for the components of the EIndex separately and robust to controlling for the presence of a compensation plan.

${ }^{13}$ For the log versions of the variable, we fill in zero for log returns for all non-takeover firm-year observations.
} 
an average increase in unconditional acquisition premiums of 36 basis points in both cases. Translating these numbers into percentages, the log specifications reported in columns (2) and (4) of Table 6 show that the presence of GPs increases one-week unconditional premiums by $3.40 \%$ and four-week unconditional premiums by $3.67 \%$. These results are not surprising in light of our earlier findings that the presence of GPs increases the likelihood of acquisitions proportionally (relative to the mean) by $26-34 \%$, while decreasing conditional premiums proportionally by approximately $13-19 \%$. In the aggregate, we find a small but positive association between GPs and unconditional premiums.

\subsection{Private Information vs. Incentives}

As we previously noted, the empirical associations documented above are consistent with both the incentives hypothesis and the private information hypothesis. We empirically examine whether the positive associations of GPs with acquisition likelihood and unconditional expected acquisition premiums are fully driven by the private information hypothesis by using the timing of GP adoption. If the adoption reflects private information regarding an elevated likelihood of a future acquisition, then the positive association between GPs and takeover likelihood should be stronger for GPs that are adopted more recently, and correspondingly, the positive association between GPs and expected acquisition premiums should be stronger for GPs that are fresh. Note that the private information hypothesis does not provide a basis for predicting that the negative association between GPs and premiums conditional on an acquisition would be different for fresh GPs than for older GPs.

To test these predictions of private information empirically, we categorize all GPs into "Fresh" and "Older" using the volume-by-volume data. We define a firm's GP to be fresh if it has been recently adopted - that is, if the firm did not have a GP in the previous IRRC volume but has a GP in the current volume; this makes the GP less than two to three years old. We define a GP to be older if it was adopted more than one volume ago - that is, if it is more than two to three years old. 
In Table 7, Panel A, columns (1) and (2) rerun the probit specifications of columns (3) and (4) of Table 6 using the volume-to-volume data, thus focusing on the association between GPs and a firm's likelihood of being acquired by the next volume. As expected, consistent with the results of Table 4, we find the coefficient of GP to be positive and statistically significant. The magnitudes of the marginal effects on GP are two to three times larger than those shown on Table 4, which is unsurprising as our dependent variable is an indicator for being acquired over the next two to three calendar years rather than in the next calendar year.

In columns (3) and (4) of Table 7, Panel A, we repeat the regressions of columns (1) and (2) except that we split GPs into "Fresh" and "Older." Controlling for the strength of takeover protection and firm characteristics, we find that the coefficients of both fresh and older GPs are positive and statistically significant. Furthermore, while the marginal effect of fresh GPs is slightly larger in magnitude than that of older GPs, we find no statistical difference between them $(p$-value $=0.324)$. These findings are consistent with the view that the positive association of GPs with acquisitions is at least partly due to incentives rather than driven solely by private information.

Panel B of Table 7 examines the associations of fresh and older GPs with unconditional expected premiums. We rerun the OLS specifications of Table 6 using volume-by-volume data instead of annual data and splitting the GP variable into fresh and older GPs. In all four regressions, we find positive and significant associations between unconditional acquisition premiums and both fresh GPs and older GPs. Estimation results using one-week [four-week] premiums reported in column (1) [(3)] show that the presence of both fresh and older GPs is associated with an average increase in unconditional acquisition premiums of 139 [115] and 99 [94] basis points, respectively.

Translating these figures into percentages, the log specifications reported in column (2) [(4)] of Table 7, Panel B, show that the presence of fresh and older GPs increases one-week [four-week] unconditional premiums by $11.1 \%$ [10.16\%] and $8.49 \%$ [8.69\%], respectively. Further, while the marginal effect of fresh GPs is somewhat lower than that of older GPs, we find no statistical difference between them in any of the four regression specifications ( $p$-value $=0.25,0.31,0.47$, and 0.53 , respectively). 
By using the timing of GP adoption, our empirical analysis suggests that the positive associations that GPs have with both likelihood of acquisition and unconditional expected premiums are not fully driven by the private information hypothesis. In unreported tests, we find that the positive and significant association of GPs with likelihood of acquisition and unconditional expected premiums are robust to the inclusion of proxies for managers' expectations of future takeover likelihood. ${ }^{14}$ Together, our results are consistent with the hypothesis that these positive associations are at least partly driven by the effect of GPs on executive incentives.

\section{GPs and Evolution of Shareholder Value}

\subsection{The Question}

Having analyzed the effects of GPs on expected acquisition premiums, we now turn to examine the overall effects of GPs on shareholder value. One way in which GPs might adversely affect shareholder value is through a "managerial slack" effect. The disciplinary force of the market for corporate control is often viewed as conducive to reducing managerial slack (Shleifer and Vishny 1989; Gompers, Ishii, and Metrick 2003). By making acquisitions less costly to executives, or even by making such acquisitions beneficial, GPs weaken the disciplinary force of the market for corporate control and can contribute to increased managerial slack (Bebchuk, Cohen, and Ferrell 2009).

In addition, GPs might have an adverse effect through what may be termed a "selling-out" effect. It is widely believed that executives might have some private information about the long-term independent value of their company (Black and Kraakman 2002). When GPs are large enough, they might give executives an incentive to go along with an acquisition even when the executives' private information indicates that doing so would not be in the shareholders' long-term interest. That is, in addition to facilitating some acquisitions that increase value from a long-term perspective, GPs that are large enough

\footnotetext{
${ }^{14}$ We control for M\&A Intensity and the Forward M\&A Intensity. M\&A Intensity is the average relative percentage of firms, relative to the cross-sectional average, in each SIC3 industry that is taken over in the years between the current IRRC and the prior IRRC volume; Forward M\&A Intensity is the average relative percentage of firms in each SIC3 industry that is taken over in the years between the current IRRC and the next IRRC volume.
} 
may facilitate some additional acquisitions that decrease value from such a perspective. Adding such acquisitions to the mix increases the expected acquisition premiums that shareholders can be expected to capture but does not serve shareholder interests; rather, it can be expected to decrease shareholders' longterm returns and, to the extent that it is reflected in current market prices, can be expected to reduce firm valuation.

Finally, we should note two positive effects that GPs might have on shareholder value. By making managers less fearful of an acquisition attempt, a GP may (i) reduce short-termism distortions and facilitate a long-term focus (Stein 1988) and (ii) encourage managers to make investments in firm-specific human capital (Jensen 1988; Shleifer and Vishny 1989).

Given the lack of an unambiguously clear theoretical prediction, empirical evidence on the subject would be useful. Prior work has shown that GPs have a negative, statistically significant, and economically meaningful correlation with Tobin's Q (Bebchuk, Cohen, and Ferrell 2009). Such a correlation could arise either because GPs have a negative effect on shareholder value or because of a selection effect (i.e., the greater tendency of low-value firms to have GPs). However, the current literature has not disentangled these two effects, and we therefore proceed to examine further the impact of GPs on shareholder value.

To examine this issue empirically, we study the evolution of shareholder value over time by considering the performance of buy-and-hold portfolios. Unlike earlier studies that examine stock returns within a short window surrounding the announcements of a GP adoption (Mogavero and Toyne 1995; Hall and Anderson 1997), we take a long-horizon approach by considering a two- to three-year window prior to, around, and after GP adoption. ${ }^{15}$ Since our portfolio return tests include acquisition premiums,

\footnotetext{
${ }^{15}$ Mogavero and Toyne (1995) focus on the 5 trading days prior to and following the announcement date, while Hall and Anderson (1997) consider a variety of event windows, with the largest extending from 20 trading days prior to the announcement date to 20 trading days following it. Event studies focusing on short windows suffer from the uncertainty about what is the appropriate date on which the GP adoption becomes public. Further, adoptions of GPs may be correlated with other changes in the firm that may be value relevant, such as changes in other aspects of the governance structure. Coates (2000) presents a summary critique of governance-related event studies. We resolve some of these difficulties, as did Gompers, Ishii, and Metrick (2003), by taking a longer-term horizon approach.
} 
this analysis allows us to combine the effects of GPs on shareholder value through both the takeover premium channel and the stand-alone value channel. We note that the buy-and-hold portfolios in our tests do not represent implementable trading strategies as they use some future information; rather, these portfolio return results represent a methodology for examining or tracking the stock performance of firms that pursue different paths over time with respect to having a GP.

\subsection{Empirical Analysis}

We begin by studying stock returns of firms in the years prior to GP adoption by considering longterm returns on the following portfolios. We go long a portfolio of stocks ("Future-Adopters") that adopt GPs two volumes from the current one (i.e., with no GPs in the current and next IRRC volumes but with GPs in the following one) while simultaneously shorting another portfolio of stocks ("Non-FutureAdopters") that do not have GPs in the current and succeeding two IRRC volumes. We consider an equalweighted portfolio and a value-weighted portfolio, weighting each stock by its common-stock market capitalization. The portfolio is rebalanced monthly; in addition, it is updated when information on firm corporate governance provisions becomes available: in September 1990, July 1993, July 1995, February 1998, November 1999, February 2002, January 2004, and January 2006 (the earliest dates on which the information in the 1990, 1993, 1995, 1998, 2000, 2002, 2004, and 2006 IRRC volumes, respectively, became publicly known). After calculating monthly returns on this portfolio, we estimate its risk-adjusted excess returns by estimating the intercept term from the standard four-factor asset-pricing model using the Fama and French (1993) three factors and the Carhart (1997) momentum factor:

$(\text { Monthly Portfolio Return })_{t}=\alpha+\beta_{1} \cdot(R m-R f)_{t}+\beta_{2} \cdot(S M B)_{t}+\beta_{3} \cdot(H M L)_{t}+\beta_{4} \cdot(\text { Carhart })_{t}+\varepsilon_{t}$ where $R m-R f_{t}, S M B_{t}$, and $H M L_{t}$ are the month $t$ market, size, and value factor returns, respectively, and Carhart $_{t}$ reflects the momentum factor return. 
Column (1), Table 8 (9) reports that the value- (equal-) weighted portfolio generates an average monthly abnormal return of -59 (-35) basis points from September 1990 to December 2003 that are statistically significant at the $1 \%$ level. On a compounded annualized basis, these translate to abnormal returns of $-6.85 \%(-4.12 \%)$, suggesting that firms that adopt GPs two IRRC volumes into the future experience an economically significant decline in stock returns relative to firms that do not adopt GPs over the same period, consistent with the hypothesis that the adoption of GPs is driven at least partially by selection.

To study the stock performance around the period of GP adoption, we consider the following portfolio strategy. We go long a portfolio of stocks (“Adopters") that adopt GPs in the next IRRC volume (i.e., not in the current volume but in the following one) while simultaneously shorting another portfolio of stocks ("Non-Adopters") that do not have GPs in the current and succeeding IRRC volumes. As above, we consider both value- and equal-weighted portfolios, rebalanced monthly, and update portfolios whenever new governance information becomes publicly available.

Column (2) in Tables 8 and 9 reports that the value-weighted and equal-weighted portfolios, respectively, produce negative and significant average abnormal monthly returns around the adoption period from September 1990 to December 2005. While the value-weighted portfolio produces average monthly abnormal returns of -37 basis points, significant at the $5 \%$ level, the equal-weighted portfolio generates average monthly abnormal returns of -20 basis points, significant at the $10 \%$ level. On a compounded annualized basis, these translate to an abnormal return of $-4.36 \%$ for the value-weighted portfolio and $2.36 \%$ for the equal-weighted portfolio, suggesting that GP adopters tend to experience a decline in stock performance relative to non-adopters around the adoption period.

Since we do not observe exact GP adoption dates, our finding of a decline in shareholder value around GP adoption might be at least partly driven by a selection effect - that is, an executive's decision to adopt a GP in response to a decrease in shareholder value between the time of one IRRC volume and the next and/or the executive's anticipation that shareholder value will decline subsequent to the next 
volume. Alternatively, these results on the intervolume change in the firm value around GP adoption might also be partly due to the negative incentive effects of GPs subsequent to their adoption.

To explore the incentive effect further, we complete the analysis by documenting the stock performance in the aftermath of GP adoption by considering the following portfolio exercise. We go long a portfolio of stocks ("LT Adopters") that has a GP in the previous, current, and subsequent IRRC volumes while simultaneously shorting another portfolio of stocks ("LT Non-Adopters") that does not have GPs in the previous, current, and succeeding IRRC volumes.

Column (3), Table 8 (9) finds that from July 1993 to December 2005, the value- (equal-) weighted portfolios produce average monthly abnormal returns of $-37(-28)$ basis points, statistically significant at the $5 \%(5 \%)$ level, translating to $-4.35 \%(-3.31 \%)$ on a compounded annualized basis. While these results are consistent with the continued erosion of shareholder value after GP adoption and thus consistent with the managerial incentive effect, it could be suggested that they are driven by a selection effect. Under this explanation, the firms with GPs that face higher acquisition likelihood but are not acquired for three consecutive IRRC volumes could be very poorly performing firms.

To explore this possibility, we rerun the above long-short strategy but include all firms acquired between the current and the next IRRC volumes. Ex ante, we should expect the inclusion of these stocks to decrease the portfolio abnormal returns, since firms with GPs are more likely to be acquired and should therefore be more likely to earn positive acquisition premiums. Column (4), Table 8 (9) reports abnormal monthly returns of $-32(-24)$ basis points for the value- (equal-) weighted portfolio, statistically significant at the 5\% (5\%) level. As expected, these returns are smaller in magnitude (by about $15 \%$ ) than those generated by excluding acquired firms, but they remain negative and statistically significant, consistent with the managerial incentive effect.

Taken together, the results on the stock returns of long-term adopters versus long-term non-adopters suggest that shareholder value tends to deteriorate in the presence of GPs. Moreover, the last set of portfolio tests, which incorporates the positive acquisition premiums earned by shareholders of long-term 
GP firms, is consistent with the hypothesis that GPs have an overall negative effect on firm value; that is, the negative effects of GPs dominate the positive effects of facilitating some value-increasing acquisitions.

\subsection{Discussion}

We thus find a pattern of deterioration in shareholder value before, around, and after GP adoption. Relative to non-adopters, future GP adopters experience a decline in shareholder value prior to adoption, consistent with selection; they continue to experience a decline in shareholder value in the window around adoption, consistent with both selection and managerial slack; finally, long-term GP adopters experience erosion in shareholder value, consistent with managerial slack.

Overall, the patterns documented here contribute to an understanding of the source of the negative association between GPs and firm value identified in prior research. Our findings are consistent with the possibility that this negative association is at least partly due to GPs bringing about, rather than merely reflecting, reduced value for shareholders.

Our findings concerning the erosion of shareholder value following GP adoption could be at least partly driven by an increased managerial slack due to the weakening effect of GPs on the disciplining forces of the market for corporate control. Our findings could also be partly driven by a selling-out effect as GPs provide executives with incentives to go along with acquisition even when the executives' private information indicates that doing so would not be in the shareholders' long-term interest. Our results indicate that the combination of managerial slack and the selling-out effect dominates the positive effects that GPs may have on shareholder value (e.g., facilitating value-increasing acquisitions, inducing a focus on the long-term, or encouraging investment in firm-specific human capital).

While we find that GPs are, on average, associated with reduced value for shareholders, we do not rule out the possibility that some types of GPs - or the use of GPs in certain circumstances - have an overall positive effect on shareholder wealth. Future empirical work may build on our findings by examining whether such types of GPs or such circumstances can be identified. Such work could assist companies in 
deciding what types of GPs to adopt and when to adopt them, and could assist shareholders in assessing the GPs adopted by companies.

\section{Conclusion}

This paper contributes to an understanding of the relationship between GPs and firm and shareholder value. We find that GPs are associated with higher expected acquisition premiums and that this association is at least partly due to the effect of GPs on executive incentives. However, we also find that, notwithstanding this association, firms adopting GPs experience negative abnormal stock returns prior to, during, and after the intervolume period of adoption.

Our findings raise the possibility that, despite their positive effect on facilitating some valueincreasing acquisitions, GPs have, on average, an overall negative effect on shareholder wealth. This average negative effect could be due to GPs increasing managerial slack and/or to GPs providing executives with incentives to go along with some acquisitions that do not serve shareholder interest.

Our findings have significant implications for ongoing debates about GPs. They also suggest the need for additional empirical work that would seek to identify the types of GPs that drive the identified correlation between GPs and reduced shareholder value. We hope that our findings contribute to the ongoing discussion and evaluation of GPs by investors and policy makers. 


\section{References}

Agrawal, Anup, and Charles Knoeber (1998). Managerial Compensation and the Threat of Takeover. Journal of Financial Economics 47, 219-339.

Bates, Thomas W., David A. Becher, and Michael L. Lemmon (2008). Board Classification and Managerial Entrenchment: Evidence from the Market for Corporate Control. Journal of Financial Economics 87, 656-677.

Bates, Thomas W. and Michael L. Lemmon (2003). Breaking up Is Hard to Do? An Analysis of Termination Fee Provisions and Merger Outcomes. Journal of Financial Economics 69, 469-504.

Bebchuk, Lucian A., Alma Cohen, and Allen Ferrell (2009). What Matters in Corporate Governance? Review of Financial Studies 22(2), 783-827.

Bebchuk, Lucian A., Alma Cohen, and Charles CY Wang (2010). Golden Parachutes and the Wealth of Shareholders. Harvard Law School John M. Olin Discussion Paper No. 683.

Black, Bernard, and Reinier Kraakman (2002), Delaware's Takeover Law: The Uncertain Search for Hidden Value. Northwestern University Law Review 95, 521-566.

Born, Jeffrey, and Emery Trahan (1993). Golden Parachutes: Incentive Aligners, Management Entrenchers, or Takeover Bid Signals. Journal of Financial Research 16, 299-308.

Brickley, James A., Jeffrey L. Coles and Rory L. Terry (1994). Outside Directors and the Adoption of Poison Pills. Journal of Financial Economics 35, 371-390.

Carhart, Mark (1997). On Persistence in Mutual Fund Performance. Journal of Finance 52, 57-82.

Coates, John (2000). Takeover Defenses in the Shadow of the Pill: A Critique of the Scientific Evidence. Texas Law Review 79, 271-382.

Comment, Robert, and G. William Schwert (1995). Poison or Placebo? Evidence on the Deterrence and Wealth Effect of Modern Antitakeover Measure. Journal of Financial Economics 39, 3-54.

Cotter, James F. and Marc Zenner (1994). How Managerial Wealth Affects the Tender Offer Process. Journal of Financial Economics 35(1), 63-97.

Cotter, James, Anil Shivdasani, and Marc Zenner (1997). Do Independent Directors Enhance Target Shareholder Wealth During Tender Offers? Journal of Financial Economics 43, 195-218.

Fama, Eugene F., and Kenneth R. French (1993). Common Risk Factors in the Returns on Bonds and Stocks. Journal of Financial Economics 33, 3-53. 
Fich, Eliezer, Anh Tran, and Ralph Walkling (2013). On the Importance of Golden Parachutes. Journal of Financial and Quantitative Analysis, Forthcoming.

Giroud, Xavier, and Holger Mueller (2011). Corporate Governance, Product Market Competition, and Equity Prices. Journal of Finance 46, 563-600.

Gompers, Paul A., Joy L. Ishii, and Andrew Metrick (2003). Corporate Governance and Equity Prices. Quarterly Journal of Economics 119, 107-155.

Grinstein, Yaniv, and Paul Hribar (2004). CEO Compensation and Incentives: Evidence from M\&A Bonuses, Journal of Financial Economics 73, 119-143.

Hall, Pamela L., and Dwight C. Anderson (1997). The Effect of Golden Parachutes on Shareholder Wealth and Takeover Probabilities. Journal of Business Finance \& Accounting 24(3-4), 445-463.

Harris, Ellie G. (1990). Antitakeover Measures, Golden Parachutes, and Target Firm Shareholder Welfare. Rand Journal of Economics 21, 614-625.

Hartzell, Jay C., Eli Ofek, and David Yermack (2004). What's in It for Me? CEOs Whose Firms are Acquired. Review of Financial Studies 17, 37-61.

Jensen, Michael (1988). Takeovers: Their Causes and Consequences. Journal of Economic Perspectives $2,21-48$.

Jenter, Dirk, and Katharina Lewellen (2011). CEO Preferences and Acquisitions. NBER Working Paper 17663.

Kahan, Marcel, and Edward Rock (2002). How I Learned to Stop Worrying and Love the Pill: Adaptive Responses to Takeover Law. University of Chicago Law Review 69, 871-916.

Kaplan, Steven N., and Luigi Zingales (1997). Do Investment-Cash Flow Sensitivities Provide Useful Measures of Financing Constraints? Quarterly Journal of Economics 112, 169-216.

Lambert, Richard A., and David F. Larcker (1985). Golden Parachutes, Executive Decision-Making, and Shareholder Wealth. Journal of Accounting and Economics 7, 179-203.

Lefanowicz, Craig E., John R. Robinson, and Reed Smith (2000). Golden Parachutes and Managerial Incentives in Corporate Acquisitions: Evidence from the 1980s and 1990s. Journal of Corporate Finance 6, 215-239.

Machlin, Judith C., Hyuk Choe, and James A. Miles (1993). The Effects of Golden Parachutes on Takeover Activity. Journal of Law and Economics 36(2), 861-876. 
Mogavero, Damian J., and Michael F. Toyne (1995). The Impact of Golden Parachutes on Fortune 500 Stock Returns: A Reexamination of Evidence. Quarterly Journal of Business and Economics 34(4), $30-38$.

Shleifer, Andrei, and Robert Vishny (1989). Management Entrenchment: The Case of Manager-Specific Investments. Journal of Financial Economics 25, 123-140.

Sokolyk, Tatyana (2011). The Effect of Antitakeover Provisions on Acquisition Targets. Journal of Corporate Finance 17, 612-627.

Stein, Jeremy (1988). Takeover Threats and Managerial Myopia. Journal of Political Economy 96, 61-80.

Wulf, Julie (2004). Do CEOs in Mergers Trade Power for Premium? Evidence from "Mergers of Equals." Journal of Law, Economics and Organization 20, 60-101. 


\section{Table 1: Summary Statistics - Stock and Adoption of GPs}

Table 1 reports summary statistics on the stock and the adoption of GPs. Panel A reports summary statistics on the stock of GPs-the number and the percentage of firms-in each IRRC volume. Panel B reports summary statistics on the adoption of GPs for those firms that appear in two consecutive IRRC volumes - the number of firms without GPs in the first of the two IRRC volumes ("Firms w/o GP Initially") but have GPs by the second volume ("Firms adopting GP" or “\% of Adopters").

Panel A: Stock of Golden Parachutes

\begin{tabular}{c|ccc}
\hline \hline & $\begin{array}{c}\text { Firms in } \\
\text { IRRC Volume }\end{array}$ & $\begin{array}{c}\text { Firms } \\
\text { IRR } / \text { GP }\end{array}$ & $\begin{array}{c}\text { \% of Firms } \\
\text { w/ GP }\end{array}$ \\
\hline \hline 1990 & 1,467 & 740 & $50.44 \%$ \\
1993 & 1,463 & 780 & $53.32 \%$ \\
1995 & 1,496 & 802 & $53.61 \%$ \\
1998 & 1,913 & 1060 & $55.41 \%$ \\
2000 & 1,886 & 1223 & $64.85 \%$ \\
2002 & 1,894 & 1282 & $67.69 \%$ \\
2004 & 1,982 & 1455 & $73.41 \%$ \\
2006 & 1,897 & 1473 & $77.65 \%$ \\
\hline \hline
\end{tabular}

Panel B: Adoption of Golden Parachutes

\begin{tabular}{ccccc}
\hline \hline Years & $\begin{array}{c}\text { Firms in both } \\
\text { IRRC Volumes }\end{array}$ & $\begin{array}{c}\text { Firms w/o } \\
\text { GP Initially }\end{array}$ & $\begin{array}{c}\text { Firms } \\
\text { adopting GP }\end{array}$ & $\begin{array}{c}\text { \% of } \\
\text { Adopters }\end{array}$ \\
\hline \hline $1990 \sim 1993$ & 1,272 & 639 & 101 & $15.81 \%$ \\
$1993 \sim 1995$ & 1,344 & 641 & 79 & $12.32 \%$ \\
$1995 \sim 1998$ & 1,214 & 594 & 142 & $23.91 \%$ \\
$1998 \sim 2000$ & 1,667 & 768 & 214 & $27.86 \%$ \\
$2000 \sim 2002$ & 1,416 & 533 & 160 & $30.02 \%$ \\
$2002 \sim 2004$ & 1,654 & 529 & 131 & $24.76 \%$ \\
$2004 \sim 2006$ & 1,656 & 455 & 100 & $21.98 \%$ \\
\hline \hline
\end{tabular}




\section{Table 2: Summary Statistics - Firms with and without GPs}

Table 2 reports means and standard deviations (in parentheses) of firm characteristics, measured on the as-of date of each IRRC volume, for all IRRC firms ("All Firms"), those IRRC firms with GPs ("GP"), and those IRRC firms without GPs ("No GP"). The last two columns report the differences in means and the statistical significance from a standard unpaired two-sided t-test. Significance levels are indicated by $*, * *$, and $* * *$ for $10 \%, 5 \%$, and $1 \%$, respectively.

\begin{tabular}{|c|c|c|c|c|c|}
\hline & All Firms & GP & No GP & Difference & \\
\hline Relative Market Cap & $\begin{array}{c}4.273 \\
(14.650)\end{array}$ & $\begin{array}{c}3.374 \\
(9.112)\end{array}$ & $\begin{array}{c}5.811 \\
(20.878)\end{array}$ & -2.4376 & *** \\
\hline Industry-Relative Q (SIC2) & $\begin{array}{l}0.4658 \\
(1.481)\end{array}$ & $\begin{array}{l}0.3440 \\
(1.231)\end{array}$ & $\begin{array}{l}0.6624 \\
(1.796)\end{array}$ & -0.3184 & *** \\
\hline Industry-Relative Debt / Asset (SIC2) & $\begin{array}{l}0.0575 \\
(0.176)\end{array}$ & $\begin{array}{l}0.0659 \\
(0.174)\end{array}$ & $\begin{array}{l}0.0432 \\
(0.180)\end{array}$ & 0.0227 & *** \\
\hline Delaware Incorporation & $\begin{array}{l}0.5582 \\
(0.497)\end{array}$ & $\begin{array}{l}0.5487 \\
(0.498)\end{array}$ & $\begin{array}{l}0.5742 \\
(0.495)\end{array}$ & -0.0255 & *** \\
\hline Herfindahl Index & $\begin{array}{l}0.1628 \\
(0.147)\end{array}$ & $\begin{array}{l}0.1601 \\
(0.145)\end{array}$ & $\begin{array}{l}0.1674 \\
(0.150)\end{array}$ & -0.0073 & *** \\
\hline Classified Board & $\begin{array}{l}0.5833 \\
(0.493)\end{array}$ & $\begin{array}{l}0.6438 \\
(0.479)\end{array}$ & $\begin{array}{l}0.4804 \\
(0.500)\end{array}$ & 0.1634 & *** \\
\hline Poison Pill & $\begin{array}{l}0.5339 \\
(0.499)\end{array}$ & $\begin{array}{l}0.6464 \\
(0.478)\end{array}$ & $\begin{array}{l}0.3425 \\
(0.475)\end{array}$ & 0.3039 & *** \\
\hline \# of Provisions in EIndex other than GP & $\begin{array}{l}1.6826 \\
(1.143)\end{array}$ & $\begin{array}{l}1.8936 \\
(1.102)\end{array}$ & $\begin{array}{l}1.3238 \\
(1.120)\end{array}$ & 0.5698 & *** \\
\hline GIndex - EIndex & $\begin{array}{l}6.7097 \\
(1.935)\end{array}$ & $\begin{array}{l}6.9048 \\
(1.886)\end{array}$ & $\begin{array}{l}6.3778 \\
(1.972)\end{array}$ & 0.5270 & $* * *$ \\
\hline Acquired by Next Volume & $\begin{array}{l}0.0960 \\
(0.295)\end{array}$ & $\begin{array}{l}0.1134 \\
(0.317)\end{array}$ & $\begin{array}{l}0.0664 \\
(0.249)\end{array}$ & 0.0471 & *** \\
\hline Number of Firms & 13,998 & 8,815 & 5,183 & & \\
\hline
\end{tabular}




\section{Table 3: Summary Statistics - Incidence of Acquisition}

Table 3 reports, as of the end of each calendar year, summary statistics on the percentage and number (in parentheses) of firms with and without GPs ("GP" and "No GP", respectively) that received an initial bid over the next calendar year and the direction of the difference (where "+" ["-"] indicates a greater [smaller] percentage of No GP firms receiving acquisition bids or being acquired in the next year). The last two rows report the time series average and standard deviation of the annual means and the differences in the annual means. Significance levels for a two-sided t-test on the null of no differences between the No GP and GP means are indicated by *, **, and *** for $10 \%, 5 \%$, and $1 \%$, respectively.

\begin{tabular}{|c|c|c|c|c|c|c|c|c|}
\hline & \multicolumn{3}{|c|}{$\begin{array}{c}\text { \% Receiving Initial Bid } \\
\text { in the Next Year }\end{array}$} & \multicolumn{5}{|c|}{$\begin{array}{c}\text { \% Acquired } \\
\text { in the Next Year }\end{array}$} \\
\hline & No GP & GP & Diff & & No GP & GP & Diff & \\
\hline 1990 & $4.6 \%(28)$ & $4.7 \%(32)$ & + & & $2.5 \%(15)$ & $2.3 \%(16)$ & - & \\
\hline 1991 & $2.7 \%(16)$ & $3.6 \%(24)$ & + & & $1.9 \%(11)$ & $2.6 \%(17)$ & + & \\
\hline 1992 & $3.0 \%(17)$ & $3.4 \%(22)$ & + & & $2.8 \%(16)$ & $3.1 \%(20)$ & + & \\
\hline 1993 & $3.2 \%(19)$ & $4.6 \%(33)$ & + & & $1.9 \%(11)$ & $2.1 \%(15)$ & + & \\
\hline 1994 & $5.8 \%(33)$ & $8.0 \%(56)$ & + & & $1.9 \%(11)$ & $5.5 \%(38)$ & + & \\
\hline 1995 & $4.0 \%(24)$ & $7.4 \%(54)$ & + & & $2.6 \%(16)$ & $4.4 \%(32)$ & + & \\
\hline 1996 & $4.8 \%(28)$ & $9.9 \%(68)$ & + & & $3.9 \%(23)$ & $8.6 \%(59)$ & + & \\
\hline 1997 & $8.4 \%(47)$ & $9.1 \%(57)$ & + & & $5.0 \%(28)$ & $7.3 \%(46)$ & + & \\
\hline 1998 & $7.8 \%(54)$ & $12.7 \%(112)$ & + & & $6.3 \%(43)$ & $10.2 \%(90)$ & + & \\
\hline 1999 & $6.2 \%(41)$ & $9.7 \%(78)$ & + & & $6.5 \%(43)$ & $9.4 \%(76)$ & + & \\
\hline 2000 & $3.7 \%(18)$ & $5.1 \%(48)$ & + & & $3.7 \%(18)$ & $5.6 \%(52)$ & + & \\
\hline 2001 & $1.9 \%(9)$ & $2.6 \%(23)$ & + & & $1.1 \%(5)$ & $2.8 \%(24)$ & + & \\
\hline 2002 & $3.5 \%(17)$ & $3.9 \%(44)$ & + & & $2.3 \%(11)$ & $2.6 \%(29)$ & + & \\
\hline 2003 & $3.2 \%(15)$ & $4.7 \%(52)$ & + & & $3.0 \%(14)$ & $4.0 \%(44)$ & + & \\
\hline 2004 & $4.3 \%(17)$ & $6.1 \%(74)$ & + & & $1.8 \%(7)$ & $4.6 \%(56)$ & + & \\
\hline 2005 & $7.0 \%(27)$ & $8.1 \%(94)$ & + & & $5.4 \%(21)$ & $4.8 \%(56)$ & - & \\
\hline 2006 & $5.3 \%(17)$ & $9.8 \%(120)$ & + & & $5.6 \%(18)$ & $8.2 \%(100)$ & + & \\
\hline Mean & $4.7 \%$ & $6.7 \%$ & $2.01 \%$ & $* * *$ & $3.4 \%$ & $5.2 \%$ & $1.76 \%$ & $* * *$ \\
\hline SD & $(0.03)$ & $(0.02)$ & & & $(0.02)$ & $(0.03)$ & & \\
\hline
\end{tabular}




\section{Table 4: Golden Parachutes and Acquisition Likelihood}

Table 4 reports the results for pooled probit regressions. For columns (1) and (2), the dependent variable is an indicator equaling 1 if the firm received a takeover bid in the next calendar year and zero otherwise; for columns (3) and (4) the dependent variable is an indicator equaling 1 if the firm was acquired in the next calendar year and zero otherwise. Standard controls are used in these specifications. Columns (1) and (2) differ according to how the industry effect is taken into account. All models estimated use cluster robust standard errors, clustering by 2-digit SIC industries, and have year fixed effects. Coefficients for industry and year fixed effects, as well as the constant term, are suppressed for ease of reporting. We report the marginal effect associated with GPs, using average values for all other controls. Significance levels are indicated by $* * *$, and $* * *$ for $10 \%, 5 \%$, and $1 \%$, respectively.

\begin{tabular}{|c|c|c|c|c|c|c|c|c|}
\hline \multirow[t]{2}{*}{ Probit Dependent Var } & \multicolumn{4}{|c|}{ Receive Bid Next Year } & \multicolumn{4}{|c|}{ Acquired Next Year } \\
\hline & (1) & & (2) & & (3) & & (4) & \\
\hline \multirow[t]{2}{*}{ Golden Parachute } & 0.0186 & *** & 0.0175 & *** & 0.0164 & *** & 0.0157 & *** \\
\hline & $(0.003)$ & & $(0.003)$ & & $(0.002)$ & & $(0.002)$ & \\
\hline \multirow[t]{2}{*}{ EIndex-GP } & -0.0037 & ** & -0.0044 & **** & -0.0013 & & -0.0018 & * \\
\hline & $(0.001)$ & & $(0.001)$ & & $(0.001)$ & & $(0.001)$ & \\
\hline \multirow[t]{2}{*}{ GIndex - EIndex } & 0.0004 & & 0.0009 & & 0.0008 & & 0.001 & * \\
\hline & $(0.001)$ & & $(0.001)$ & & $(0.001)$ & & $(0.001)$ & \\
\hline \multirow[t]{2}{*}{ Delaware Inc } & 0.0111 & ${ }^{* * *}$ & 0.0092 & *** & 0.007 & *** & 0.0071 & *** \\
\hline & $(0.003)$ & & $(0.003)$ & & $(0.002)$ & & $(0.002)$ & \\
\hline \multirow[t]{2}{*}{$\log (\mathrm{Q})$} & -0.0147 & *** & -0.0194 & *** & -0.0048 & * & -0.0069 & ** \\
\hline & $(0.004)$ & & $(0.004)$ & & $(0.003)$ & & $(0.003)$ & \\
\hline \multirow[t]{2}{*}{$\log ($ Asset $)$} & -0.0029 & **** & -0.0058 & *** & -0.0023 & *** & -0.0041 & *** \\
\hline & $(0.001)$ & & $(0.001)$ & & $(0.001)$ & & $(0.001)$ & \\
\hline \multirow[t]{2}{*}{ Log(Debt/Asset) } & 0.0089 & & 0.0157 & ** & -0.0047 & & -0.0029 & \\
\hline & $(0.008)$ & & $(0.008)$ & & $(0.006)$ & & $(0.007)$ & \\
\hline \multirow[t]{2}{*}{ Inside Ownership } & -0.0004 & & -0.0006 & ** & -0.0002 & & -0.0003 & \\
\hline & $(0.000)$ & & $(0.000)$ & & $(0.000)$ & & $(0.000)$ & \\
\hline \multirow[t]{2}{*}{ Log(CEO Age $)$} & 0.0029 & & 0.0055 & & -0.0008 & & 0.0002 & \\
\hline & $(0.015)$ & & $(0.014)$ & & $(0.013)$ & & $(0.012)$ & \\
\hline \multirow[t]{2}{*}{$\log (\mathrm{CEO}$ Tenure $)$} & -0.0038 & ** & -0.0039 & *** & -0.0016 & & -0.0017 & \\
\hline & $(0.002)$ & & $(0.001)$ & & $(0.001)$ & & $(0.001)$ & \\
\hline \multirow[t]{2}{*}{ Herfindahl Index } & -0.0387 & ${ }^{* * *}$ & & & -0.0302 & *** & & \\
\hline & $(0.011)$ & & & & $(0.009)$ & & & \\
\hline Dependent Var Mean & 0.0596 & & 0.0598 & & 0.0454 & & 0.0456 & \\
\hline Proportional Marginal Effect & 0.3121 & & 0.2926 & & 0.3612 & & 0.3443 & \\
\hline Industry FE & No & & Yes & & No & & Yes & \\
\hline Pseudo R-squared & 0.0400 & & 0.0580 & & 0.0640 & & 0.0800 & \\
\hline Observations & 23,794 & & 23,732 & & 23,794 & & 23,662 & \\
\hline
\end{tabular}




\section{Table 5: Golden Parachutes and Premiums in Acquisitions}

Table 5 reports pooled regression results of one-week and four-week acquisition premiums on target firm governance characteristics, fundamentals, and deal characteristics. Columns (1) and (2) use one-week premium and log of one-week premium as the dependent variables; columns (3) and (4) use four-week premium and log of fourweek premium as the dependent variables. All models include estimated 2-digit SIC industry and year fixed effects, and all estimations use cluster robust standard errors, clustering by 2-digit SIC industries, and have year and SIC2 industry fixed effects. Coefficients for year and industry fixed effects and the constant term are suppressed. Significance levels are indicated by $* * *$, and $* * *$ for $10 \%, 5 \%$, and $1 \%$, respectively.

\begin{tabular}{|c|c|c|c|c|c|c|c|c|}
\hline \multirow{2}{*}{ Dependent Var } & \multirow{2}{*}{\multicolumn{2}{|c|}{$\begin{array}{c}\text { 1Wk Prem } \\
(1)\end{array}$}} & \multirow{2}{*}{\multicolumn{2}{|c|}{$\begin{array}{c}\ln (1 W k \text { Prem) } \\
\text { (2) }\end{array}$}} & \multirow{2}{*}{\multicolumn{2}{|c|}{$\begin{array}{c}\text { 4Wk Prem } \\
(3)\end{array}$}} & \multirow{2}{*}{\multicolumn{2}{|c|}{$\frac{\ln (4 W k \text { Prem })}{(4)}$}} \\
\hline & & & & & & & & \\
\hline \multirow[t]{2}{*}{ Golden Parachute } & -0.0352 & ** & -0.1298 & ${ }^{*}$ & -0.0388 & * & -0.1828 & "** \\
\hline & $(0.017)$ & & $(0.078)$ & & $(0.020)$ & & $(0.089)$ & \\
\hline \multirow[t]{2}{*}{ EIndex-GP } & 0.0188 & *** & 0.0511 & * & 0.0147 & & 0.0362 & \\
\hline & $(0.007)$ & & $(0.026)$ & & $(0.009)$ & & $(0.029)$ & \\
\hline \multirow[t]{2}{*}{ GIndex-EIndex } & 0.0047 & & 0.0154 & & -0.0016 & & -0.0043 & \\
\hline & $(0.004)$ & & $(0.019)$ & & $(0.005)$ & & $(0.015)$ & \\
\hline \multirow[t]{2}{*}{ Delaware Inc } & 0.0091 & & -0.033 & & 0.0125 & & -0.0193 & \\
\hline & (0.014) & & $(0.057)$ & & $(0.017)$ & & $(0.070)$ & \\
\hline \multirow[t]{2}{*}{$\log (\mathrm{Q})$} & -0.028 & & -0.0071 & & -0.0289 & & -0.0051 & \\
\hline & $(0.025)$ & & $(0.066)$ & & $(0.036)$ & & $(0.087)$ & \\
\hline \multirow[t]{2}{*}{ Log(Assets) } & -0.0189 & & -0.0433 & & -0.022 & & -0.0631 & \\
\hline & $(0.009)$ & & $(0.035)$ & & $(0.009)$ & & $(0.031)$ & \\
\hline \multirow[t]{2}{*}{ Debt/Asset } & 0.0602 & ** & 0.1999 & & 0.0386 & ** & 0.2472 & ** \\
\hline & $(0.048)$ & & $(0.199)$ & & $(0.047)$ & & $(0.170)$ & \\
\hline \multirow[t]{2}{*}{ Inside Ownership } & -0.0011 & & 0.0011 & & -0.0022 & & -0.0047 & \\
\hline & $(0.002)$ & & $(0.006)$ & & $(0.002)$ & & $(0.008)$ & \\
\hline \multirow[t]{2}{*}{ Hostile Bid } & 0.0968 & * & 0.2695 & * & 0.0579 & & 0.2974 & ${ }^{* * * *}$ \\
\hline & $(0.054)$ & & $(0.140)$ & & $(0.040)$ & & $(0.106)$ & \\
\hline \multirow[t]{2}{*}{ Tender Offer } & 0.0639 & * & 0.2283 & ** & 0.1033 & ${ }^{* * *}$ & 0.2694 & *** \\
\hline & $(0.033)$ & & $(0.090)$ & & $(0.037)$ & & $(0.114)$ & \\
\hline \multirow[t]{2}{*}{ Toehold } & -0.001 & & -0.0037 & & -0.002 & & -0.0027 & \\
\hline & $(0.002)$ & & $(0.006)$ & & $(0.001)$ & & $(0.005)$ & \\
\hline \multirow[t]{2}{*}{ Termination Fee } & -0.007 & & -0.0013 & & -0.0004 & & 0.1221 & \\
\hline & $(0.023)$ & & $(0.070)$ & & $(0.021)$ & & $(0.089)$ & \\
\hline \multirow[t]{2}{*}{ Stock Swap } & -0.0105 & & -0.1555 & * & -0.0175 & & -0.1631 & $*$ \\
\hline & $(0.025)$ & & $(0.081)$ & & $(0.024)$ & & $(0.084)$ & \\
\hline \multirow[t]{2}{*}{ Log(Time) } & 0.0143 & & 0.0447 & & 0.0106 & & 0.0373 & \\
\hline & $(0.021)$ & & $(0.066)$ & & $(0.024)$ & & $(0.067)$ & \\
\hline \multirow[t]{2}{*}{ Log(CEO Age $)$} & -0.0904 & & -0.4266 & & -0.1927 & & -0.8904 & ${ }^{* *}$ \\
\hline & $(0.132)$ & & $(0.483)$ & & $(0.126)$ & & $(0.410)$ & \\
\hline \multirow[t]{2}{*}{$\log (\mathrm{CEO}$ Tenure $)$} & 0.0185 & & 0.0988 & ** & 0.0139 & & 0.064 & \\
\hline & $(0.019)$ & & $(0.047)$ & & $(0.021)$ & & $(0.049)$ & \\
\hline Adjusted $\mathrm{R}^{2}$ & 0.1110 & & 0.0770 & & 0.1460 & & 0.0730 & \\
\hline Observations & 773 & & 773 & & 770 & & 770 & \\
\hline
\end{tabular}




\section{Table 6: Golden Parachutes and Expected Premiums from Acquisitions}

Table 6 reports pooled regression results of one-week and four-week acquisition premiums on target firm governance characteristics and fundamentals across all firms in the annual IRRC dataset, where any firm that did not undergo a completed acquisition over the next year has an acquisition premium of 0 . Columns (1) and (2) use oneweek premium and $\log$ of one-week premium as the dependent variables; columns (3) and (4) use four-week premium and $\log$ of four-week premium as the dependent variables. All models include estimated 2-digit SIC industry and year fixed effects, and all estimations use cluster robust standard errors, clustering by 2-digit SIC industries, and have year and SIC2 industry fixed effects. Coefficients for year and industry fixed effects and the constant term are suppressed. Significance levels are indicated by *, **, and *** for $10 \%, 5 \%$, and $1 \%$, respectively.

\begin{tabular}{|c|c|c|c|c|c|c|c|c|}
\hline \multirow{3}{*}{$\begin{array}{l}\text { Dependent Var } \\
\text { Golden Parachute }\end{array}$} & \multirow{2}{*}{\multicolumn{2}{|c|}{$\begin{array}{c}\text { 1Wk Prem } \\
(1)\end{array}$}} & \multirow{2}{*}{\multicolumn{2}{|c|}{$\begin{array}{c}\log (1 \mathrm{Wk} \text { Prem) } \\
(2)\end{array}$}} & \multirow{2}{*}{\multicolumn{2}{|c|}{$\begin{array}{c}\text { 4Wk Prem } \\
\text { (3) }\end{array}$}} & \multirow{2}{*}{\multicolumn{2}{|c|}{$\begin{array}{c}\log (4 \text { Wk Prem) } \\
(4)\end{array}$}} \\
\hline & & & & & & & & \\
\hline & $\begin{array}{r}0.0033 \\
(0.001)\end{array}$ & ${ }^{* * *}$ & $\begin{array}{r}0.0345 \\
(0.008)\end{array}$ & $* * *$ & $\begin{array}{r}0.0033 \\
(0.001)\end{array}$ & ${ }^{* * *}$ & $\begin{array}{l}0.0327 \\
(0.008)\end{array}$ & $* * *$ \\
\hline EIndex-GP & $\begin{array}{r}0.0002 \\
(0.000)\end{array}$ & & $\begin{array}{r}-0.0020 \\
(0.003)\end{array}$ & & $\begin{array}{l}0.0000 \\
(0.000)\end{array}$ & & $\begin{array}{r}-0.0024 \\
(0.003)\end{array}$ & \\
\hline GIndex-EIndex & $\begin{array}{r}0.0000 \\
(0.000)\end{array}$ & & $\begin{array}{r}-0.0006 \\
(0.002)\end{array}$ & & $\begin{array}{r}-0.0003 \\
(0.000)\end{array}$ & & $\begin{array}{r}-0.0013 \\
(0.002)\end{array}$ & \\
\hline Delaware Inc & $\begin{array}{r}0.0020 \\
(0.001)\end{array}$ & * & $\begin{array}{r}0.0155 \\
(0.009)\end{array}$ & & $\begin{array}{l}0.0022 \\
(0.001)\end{array}$ & * & $\begin{array}{r}0.0159 \\
(0.010)\end{array}$ & \\
\hline $\log (\mathrm{Q})$ & $\begin{array}{r}-0.0032 \\
(0.001)\end{array}$ & *** & $\begin{array}{r}-0.0206 \\
(0.011)\end{array}$ & * & $\begin{array}{r}-0.0033 \\
(0.001)\end{array}$ & ** & $\begin{array}{r}-0.0195 \\
(0.012)\end{array}$ & \\
\hline Log(Assets) & $\begin{array}{r}-0.0025 \\
(0.000)\end{array}$ & ${ }^{* * *}$ & $\begin{array}{r}-0.0206 \\
(0.003)\end{array}$ & ${ }^{* * *}$ & $\begin{array}{r}-0.0029 \\
(0.000)\end{array}$ & *** & $\begin{array}{r}-0.0219 \\
(0.003)\end{array}$ & *** \\
\hline Debt/Asset & $\begin{array}{r}-0.0012 \\
(0.003)\end{array}$ & & $\begin{array}{r}-0.0199 \\
(0.027)\end{array}$ & & $\begin{array}{l}0.0008 \\
(0.005)\end{array}$ & & $\begin{array}{r}-0.0014 \\
(0.034)\end{array}$ & \\
\hline Inside Ownership & $\begin{array}{r}-0.0002 \\
(0.000)\end{array}$ & $* * *$ & $\begin{array}{r}-0.0014 \\
(0.001)\end{array}$ & ** & $\begin{array}{r}-0.0002 \\
(0.000)\end{array}$ & $* * *$ & $\begin{array}{r}-0.0014 \\
(0.001)\end{array}$ & $* *$ \\
\hline Log(CEO Age $)$ & $\begin{array}{r}-0.0004 \\
(0.003)\end{array}$ & & $\begin{array}{l}0.0232 \\
(0.028)\end{array}$ & & $\begin{array}{l}0.0001 \\
(0.005)\end{array}$ & & $\begin{array}{l}0.0183 \\
(0.032)\end{array}$ & \\
\hline $\log (\mathrm{CEO}$ Tenure $)$ & $\begin{array}{r}0.0003 \\
(0.000)\end{array}$ & & $\begin{array}{r}0.0000 \\
(0.004)\end{array}$ & & $\begin{array}{r}0.0002 \\
(0.000) \\
\end{array}$ & & $\begin{array}{r}0.0007 \\
(0.004)\end{array}$ & \\
\hline Adjusted $\mathrm{R}^{2}$ & 0.013 & & 0.017 & & 0.015 & & 0.018 & \\
\hline Observations & 23,577 & & 23,577 & & 23,577 & & 23,574 & \\
\hline
\end{tabular}




\section{Table 7: Fresh vs. Older GPs}

Panel A: Fresh and Older GPs and Acquisition Likelihood

Table 7 reports marginal effects from pooled probit results. Results from columns (1) and (2) are comparable to those in Table 5, with the difference being that the dependent variable is an indicator for whether a firm was acquired by the current date of publication for the next IRRC volume. Columns (3) and (4) represent the same models as columns (1) and (2), respectively, but differentiate between "Old" and "Fresh" GPs, where fresh GP equals 1 if a firm does not have a GP in the previous IRRC volume but has GP in the current volume, and old GP equals 1 if a firm has a GP in both the previous and current IRRC volumes. All models estimated use robust cluster standard errors. Specifications (1) and (3) use the Herfindahl Index as industry control, while (2) and (4) use 2-digit SIC industry fixed effects. Standard errors are reported below marginal effects in parentheses. Marginal effects for industry and year fixed effects, as well as the constant term, are not displayed. Significance levels are indicated by *, $* *$, and $* * *$ for $10 \%, 5 \%$, and $1 \%$, respectively.

\begin{tabular}{|c|c|c|c|c|c|c|c|c|}
\hline \multirow{3}{*}{$\begin{array}{l}\text { Probit Dependent Var } \\
\text { Golden Parachute }\end{array}$} & \multicolumn{4}{|c|}{ Acquired by Next IRRC Vol } & \multicolumn{4}{|c|}{ Acquired by Next IRRC Vol } \\
\hline & \multicolumn{2}{|c|}{ (1) } & \multicolumn{2}{|c|}{ (2) } & \multicolumn{2}{|c|}{ (3) } & \multicolumn{2}{|c|}{ (4) } \\
\hline & $\begin{array}{l}0.0328 \\
(0.005)\end{array}$ & ${ }^{* * * *}$ & $\begin{array}{l}0.0326 \\
(0.005)\end{array}$ & $* * *$ & & & & \\
\hline Fresh GP & & & & & $\begin{array}{l}0.0395 \\
(0.012)\end{array}$ & $* * *$ & $\begin{array}{l}0.0404 \\
(0.012)\end{array}$ & *** \\
\hline Older GP & & & & & $\begin{array}{l}0.0302 \\
(0.006)\end{array}$ & $* * *$ & $\begin{array}{l}0.0319 \\
(0.006)\end{array}$ & *** \\
\hline EIndex-GP & $\begin{array}{r}-0.0012 \\
(0.002)\end{array}$ & & $\begin{array}{r}-0.0019 \\
(0.002)\end{array}$ & & $\begin{array}{r}-0.0001 \\
(0.002)\end{array}$ & & $\begin{array}{r}-0.0009 \\
(0.002)\end{array}$ & \\
\hline GIndex - EIndex & $\begin{array}{l}0.0014 \\
(0.001)\end{array}$ & & $\begin{array}{l}0.0019 \\
(0.001)\end{array}$ & & $\begin{array}{c}0.0011 \\
(0.001)\end{array}$ & & $\begin{array}{l}0.0016 \\
(0.001)\end{array}$ & \\
\hline Delaware Inc & $\begin{array}{c}0.0151 \\
(0.005)\end{array}$ & & $\begin{array}{l}0.0144 \\
(0.005)\end{array}$ & $*$ & $\begin{array}{l}0.0162 \\
(0.005)\end{array}$ & $* * *$ & $\begin{array}{l}0.0157 \\
(0.005)\end{array}$ & *** \\
\hline $\log (Q)$ & $\begin{array}{l}-0.0041 \\
(0.005)\end{array}$ & $* * *$ & $\begin{array}{r}-0.0089 \\
(0.005)\end{array}$ & ${ }^{* * *}$ & $\begin{array}{l}-0.0031 \\
(0.005)\end{array}$ & & $\begin{array}{l}-0.0078 \\
(0.005)\end{array}$ & \\
\hline Log(Assets) & $\begin{array}{r}-0.0057 \\
(0.002)\end{array}$ & & $\begin{array}{r}-0.009 \\
(0.002)\end{array}$ & & $\begin{array}{l}-0.0062 \\
(0.002)\end{array}$ & *** & $\begin{array}{r}-0.0099 \\
(0.002)\end{array}$ & *** \\
\hline Debt/Assets & $\begin{array}{l}0.0024 \\
(0.012)\end{array}$ & ${ }^{* * *}$ & $\begin{array}{l}0.0078 \\
(0.012)\end{array}$ & $* * *$ & $\begin{array}{l}0.0055 \\
(0.012)\end{array}$ & & $\begin{array}{l}0.0111 \\
(0.013)\end{array}$ & \\
\hline Inside Ownership & $\begin{array}{l}-0.0016 \\
(0.000)\end{array}$ & $* * *$ & $\begin{array}{r}-0.0017 \\
(0.000)\end{array}$ & $* * *$ & $\begin{array}{c}-0.0016 \\
(0.000)\end{array}$ & $* * *$ & $\begin{array}{r}-0.0017 \\
(0.000)\end{array}$ & *** \\
\hline Log(CEO Age $)$ & $\begin{array}{c}-0.0092 \\
(0.028)\end{array}$ & & $\begin{array}{c}-0.0068 \\
(0.027)\end{array}$ & & $\begin{array}{l}-0.0102 \\
(0.028)\end{array}$ & & $\begin{array}{c}-0.0078 \\
(0.027)\end{array}$ & \\
\hline $\log ($ CEO Tenure $)$ & $\begin{array}{l}-0.0048 \\
(0.003)\end{array}$ & $*$ & $\begin{array}{r}-0.0053 \\
(0.003)\end{array}$ & ** & $\begin{array}{r}-0.0049 \\
(0.003)\end{array}$ & * & $\begin{array}{l}-0.0055 \\
(0.003)\end{array}$ & ** \\
\hline Herfindahl Index & $\begin{array}{r}-0.0358 \\
(0.018) \\
\end{array}$ & ** & & & $\begin{array}{r}-0.0369 \\
(0.018) \\
\end{array}$ & ${ }^{* *}$ & & \\
\hline Dependent Var Mean & 0.0985 & & 0.0990 & & 0.0985 & & 0.0990 & \\
\hline Proportional Marginal Effect & 0.3330 & & 0.3293 & & $\begin{array}{r}0.4010 \\
{[0.3066]} \\
\end{array}$ & & $\begin{array}{r}0.4081 \\
{[0.3222]} \\
\end{array}$ & \\
\hline Industry FE & No & & Yes & & No & & Yes & \\
\hline Pseudo $\mathrm{R}^{2}$ & 0.1930 & & 0.2080 & & 0.1920 & & 0.2070 & \\
\hline Observations & 12,236 & & 12,173 & & 12,236 & & 12,173 & \\
\hline
\end{tabular}


Panel B: Fresh and Older GPs and Expected Premiums from Acquisitions

This table reports pooled regression results of one-week and four-week acquisition premiums on target firm governance characteristics and fundamentals across all firms in the IRRC volume dataset, where any firm that did not undergo a completed acquisition over the next year has an acquisition premium of 0 . Columns (1) and (2) use one-week premium and log of one-week premium as the dependent variables; columns (3) and (4) use four-week premium and $\log$ of four-week premium as the dependent variables. All models include estimated 2-digit SIC industry and year fixed effects, and all estimations use cluster robust standard errors, clustering by 2-digit SIC industries, and have year and SIC2 industry fixed effects. Coefficients for year and industry fixed effects and the constant term are suppressed. Significance levels are indicated by *, **, and *** for $10 \%, 5 \%$, and $1 \%$, respectively.

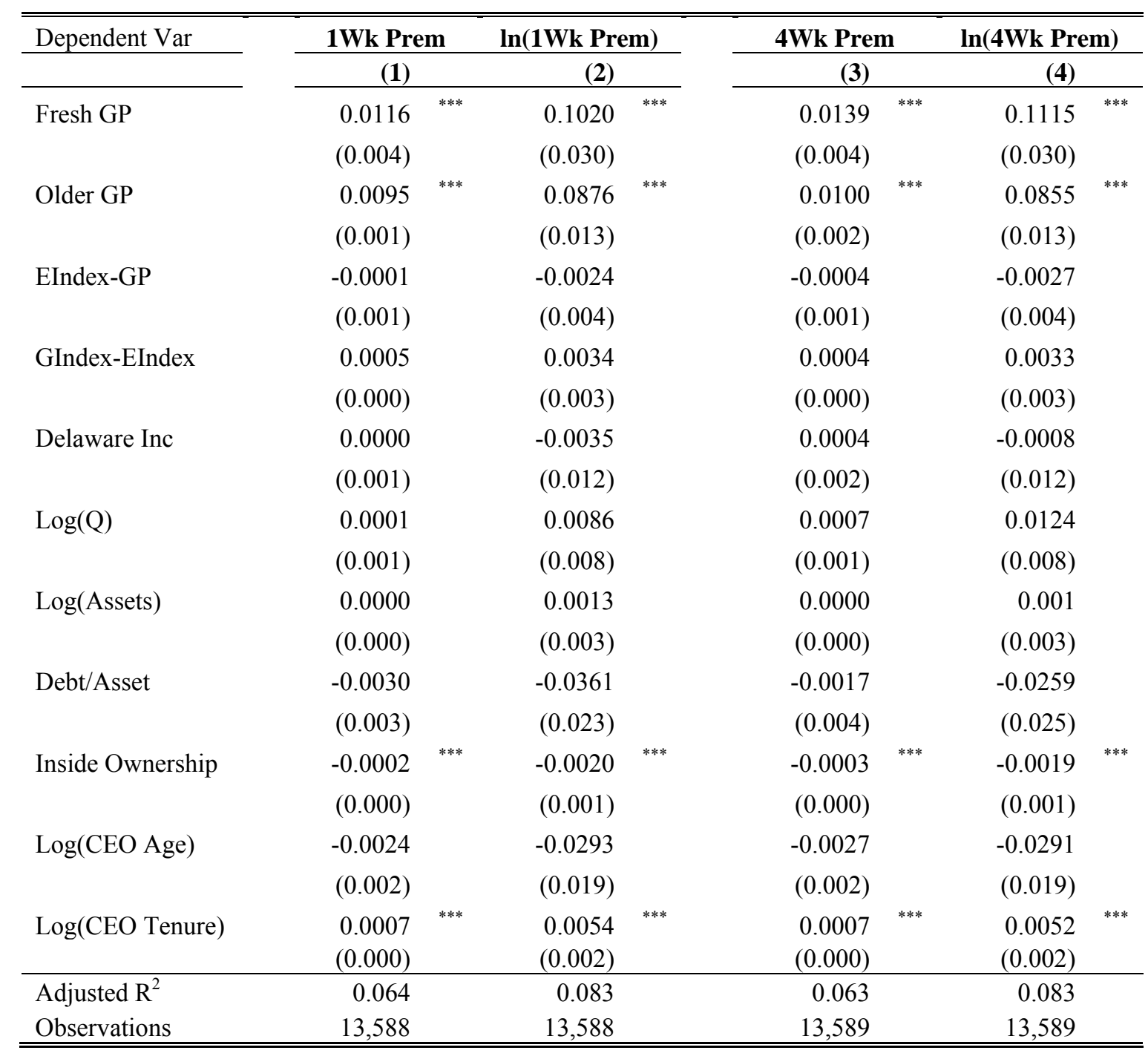




\section{Table 8: Stock Returns and Golden Parachutes: Value-Weighted}

Table 8 Panel A (B) reports monthly abnormal returns estimated from regressing monthly value-weighted "VW" (equal-weighted "EW") portfolio returns on the three Fama-French (Fama and French 1993) factors and the Carhart (1997) momentum factor. Column (1) in each panel considers the strategy for the period September 1990-December 2003 that goes long a portfolio of stocks that adopt GPs two volumes from the current one (i.e., do not have GPs in the current and next IRRC volumes but do have GPs in the following one) and simultaneously shorts the portfolio of stocks that do not have GPs in the current and succeeding two IRRC volumes. Column (2) in each panel considers the trading strategy for the period September 1990-December 2005 that goes long a portfolio of stocks that adopt GPs in the next IRRC volume and simultaneously shorts the portfolio of stocks that do not have GPs between the current and succeeding IRRC volumes. Columns (3) and (4) consider the trading strategy for the period July 1993December 2005 that goes long the portfolio of stocks that have GPs as of the current date in the previous IRRC volume as well as in the next IRRC volumes and simultaneously shorts the portfolio of stocks that do not have GPs in the previous, current, and next IRRC volumes. Column (4) differs from column (3) by including all firms acquired between the current and the following IRRC volumes, and reinvesting toward the rest of the respective portfolio on the long and the short side. None of the strategies is implementable in real time as each requires future information. Long and short portfolios were adjusted when updated information on firm corporate governance provisions became available: July 1993; July 1995; February 1998; February 2000; February 2002; January 2004; January 2006. Robust standard errors are reported in parentheses below the coefficients, and levels of significance are indicated by $*, * *$, and $* * *$ for $10 \%, 5 \%$, and $1 \%$, respectively.

\begin{tabular}{|c|c|c|c|c|c|c|c|c|}
\hline Dep Var & \multicolumn{8}{|c|}{ Monthly VW Portfolio Returns } \\
\hline Long: & \multicolumn{2}{|c|}{$\begin{array}{c}\text { (1) } \\
\text { Future-Adopters }\end{array}$} & $\begin{array}{r}\text { (2) } \\
\text { Adopters }\end{array}$ & & $\begin{array}{c}(3) \\
\text { LT Adopter }\end{array}$ & & \multicolumn{2}{|c|}{$\begin{array}{c}(4) \\
\text { LT Adopters } \\
\text { (w/ acquired) }\end{array}$} \\
\hline Short: & \multicolumn{2}{|c|}{$\begin{array}{c}\text { Non- } \\
\text { Future-Adopters }\end{array}$} & \multicolumn{2}{|c|}{ Non-Adopters } & \multicolumn{2}{|c|}{ LT Non-Adopters } & \multicolumn{2}{|c|}{$\begin{array}{l}\text { LT Non-Adopters } \\
\text { (w/ acquired) }\end{array}$} \\
\hline \multirow[t]{2}{*}{ Alpha } & -0.0059 & $* * *$ & -0.0037 & $* * *$ & -0.0037 & ** & -0.0032 & $* *$ \\
\hline & $(0.002)$ & & $(0.002)$ & & $(0.001)$ & & $(0.001)$ & \\
\hline \multirow[t]{2}{*}{$\mathrm{Rm}-\mathrm{Rf}$} & 0.0034 & & -0.032 & & 0.0183 & & 0.0155 & \\
\hline & $(0.056)$ & & $(0.040)$ & & $(0.039)$ & & $(0.040)$ & \\
\hline \multirow[t]{2}{*}{ SMB } & 0.0834 & & 0.2017 & *** & 0.1203 & $* * *$ & 0.1189 & \\
\hline & $(0.067)$ & & $(0.050)$ & & $(0.040)$ & & $(0.041)$ & \\
\hline \multirow[t]{2}{*}{ HML } & 0.2827 & *** & 0.212 & *** & 0.5274 & $* * *$ & 0.5306 & *** \\
\hline & $(0.096)$ & & $(0.066)$ & & $(0.062)$ & & $(0.062)$ & \\
\hline \multirow[t]{2}{*}{ Carhart } & -0.0175 & & -0.0585 & & 0.0285 & & 0.0269 & \\
\hline & $(0.043)$ & & $(0.025)$ & & $(0.028)$ & & $(0.028)$ & \\
\hline $\mathrm{N}$ & 160 & & 184 & & 150 & & 150 & \\
\hline Adj. $R^{2}$ & 0.0861 & & 0.1185 & & 0.5094 & & 0.5156 & \\
\hline
\end{tabular}




\section{Table 9: Stock Returns and Golden Parachutes - Equal-Weighted}

Table 9 Panel A (B) reports monthly abnormal returns estimated from regressing monthly value-weighted "VW" (equal-weighted "EW") portfolio returns on the three Fama-French (Fama and French 1993) factors and the Carhart (1997) momentum factor. Column (1) in each panel considers the strategy for the period September 1990-December 2003 that goes long a portfolio of stocks that adopt GPs two volumes from the current one (i.e., do not have GPs in the current and next IRRC volumes but do have GPs in the following one) and simultaneously shorts the portfolio of stocks that do not have GPs in the current and succeeding two IRRC volumes. Column (2) in each panel considers the trading strategy for the period September 1990-December 2005 that goes long a portfolio of stocks that adopt GPs in the next IRRC volume and simultaneously shorts the portfolio of stocks that do not have GPs between the current and succeeding IRRC volumes. Columns (3) and (4) consider the trading strategy for the period July 1993December 2005 that goes long the portfolio of stocks that have GPs as of the current date in the previous IRRC volume as well as in the next IRRC volumes and simultaneously shorts the portfolio of stocks that do not have GPs in the previous, current, and next IRRC volumes. Column (4) differs from column (3) by including all firms acquired between the current and the following IRRC volumes, and reinvesting toward the rest of the respective portfolio on the long and the short side. None of the strategies is implementable in real time as each requires future information. Long and short portfolios were adjusted when updated information on firm corporate governance provisions became available: July 1993; July 1995; February 1998; February 2000; February 2002; January 2004; January 2006. Robust standard errors are reported in parentheses below the coefficients, and levels of significance are indicated by $*, * *$, and $* * *$ for $10 \%, 5 \%$, and $1 \%$, respectively.

\begin{tabular}{|c|c|c|c|c|c|c|c|c|}
\hline Dep Var & \multicolumn{8}{|c|}{ Monthly EW Portfolio Returns } \\
\hline Long: & \multicolumn{2}{|c|}{$\begin{array}{c}\text { (1) } \\
\text { Future-Adopters }\end{array}$} & \multicolumn{2}{|c|}{$\begin{array}{c}(2) \\
\text { Adopters }\end{array}$} & \multicolumn{2}{|c|}{$\begin{array}{c}(3) \\
\text { LT Adopters }\end{array}$} & \multicolumn{2}{|c|}{$\begin{array}{c}\text { (4) } \\
\text { LT Adopters } \\
\text { (w/ acquired) }\end{array}$} \\
\hline Short: & \multicolumn{2}{|c|}{$\begin{array}{l}\text { Non- } \\
\text { Future-Adopters }\end{array}$} & \multicolumn{2}{|c|}{ Non-Adopters } & \multicolumn{2}{|c|}{ LT Non-Adopters } & \multicolumn{2}{|c|}{$\begin{array}{l}\text { LT Non-Adopters } \\
\text { (w/ acquired) }\end{array}$} \\
\hline \multirow[t]{2}{*}{ Alpha } & -0.0059 & *** & -0.002 & * & -0.0028 & $* * *$ & -0.0024 & $* *$ \\
\hline & -0.002 & & -0.001 & & -0.001 & & -0.001 & \\
\hline \multirow[t]{2}{*}{$\mathrm{Rm}-\mathrm{Rf}$} & 0.0034 & & -0.0195 & & 0.0127 & & 0.013 & \\
\hline & -0.056 & & -0.027 & & -0.021 & & -0.023 & \\
\hline \multirow[t]{2}{*}{ SMB } & 0.0834 & & 0.131 & $* * *$ & 0.0242 & & 0.0141 & \\
\hline & -0.067 & & -0.037 & & -0.028 & & -0.03 & \\
\hline \multirow[t]{2}{*}{ HML } & 0.2827 & *** & 0.0942 & * & 0.2904 & *** & 0.2866 & *** \\
\hline & -0.096 & & -0.051 & & -0.031 & & -0.033 & \\
\hline \multirow[t]{2}{*}{ Carhart } & -0.0175 & & -0.1262 & *** & 0.0063 & & 0.0133 & \\
\hline & -0.043 & & -0.024 & & -0.013 & & -0.013 & \\
\hline $\mathrm{N}$ & 160 & & 184 & & 150 & & 150 & \\
\hline Adj. $\mathrm{R}^{2}$ & 0.0861 & & 0.2695 & & 0.4876 & & 0.4755 & \\
\hline
\end{tabular}

